\title{
The Improvement of Local Shipping Safety in Makassar
}

\author{
Joe Ronald K. Bokau \\ Indonesian Ministry of Transportation, Barombong Maritime Polytechnic" \\ Jln. Permandian Alam No.1, Barombong - Makassar, Sulawesi Selatan \\ e-mail: poltekpelbarombong@gmail.com
}

\begin{abstract}
Traditional Shipping is a traditional business of the people and has its own characteristics to carry out transportation in waters using sailing ships including Pinisi, Motorized Sailing Ships, and/or simple motorized boats of a certain size. Accidents in people's voyages still often occur in the waters of Makassar City. This study aims to analyze the improvement of local shipping safety in Makassar. This research is a qualitative descriptive method using SWOT analysis. The results of this study show 1). Seaworthiness Conditions of Traditional Ships regarding the implementation of procedures, information on weather conditions, seaworthiness conditions were in the very good category $53.3 \%$ and good category by $46.7 \%$. 2). safety management and supervision of sea transportation in Makassar City have performed in accordance with applicable regulations and procedures so that the services provided in the excellent category were $50.0 \%$, in the good category at $46.7 \%$, and in the poor category $3.3 \%$. 3 ). Plans to reduce shipping accidents in Makassar, namely the establishment of the Syandu Program (Syahbandar Education) program and conducting field supervision on $1 \mathrm{x}$ vessels are in a good category at $60.0 \%$ and in the very good category at $40.0 \%$
\end{abstract}

Keywords: Traditional, Shipping, Safety, Security, Makassar

\section{Introduction}

Maritime safety and security in the shipping, the industry has adopted a number of international regulations issued by the International Maritime Organization (IMO) such as SOLAS, ISM Code, ISPS Code and others. There have even been efforts to increase the reliability of ship systems to reduce accident rates and improve efficiency, but the rate of maritime accidents is still high (Rothblum et al., 2002). The DirectorGeneral of Sea Transportation issues regulation No. HK.103/2/8/DJPL-17 dated 18 April 2017 concerning Traditional Passenger Carrier Ship Guidance, in order to ensure the safety of traditional passenger ships and as a condition of eligibility for traditional passenger transport vessels in Indonesian waters (http://hubla.dephub.go.id/).

Makassar is the capital of South Sulawesi Province which has 12 islands, among others: Lae-Lae, Kayangan, Gusung Tallang, Samalona, Kodingareng Lompo, Kodingareng Keke, Barrang Lompo, Barrang Caddi, Bonetambung, Lumu Lumu, Langkai and Lanjukang (www.makassarkota. go.id, 2019). To connect these areas, traditional sea transportation modes such as Jolloro, Katinting, Karoro, and Patorani are used to catch fish. However, in practice it is used to transport passengers and goods because of the transportation user does not have other means of transportation to land or return to the island unless using these types of boats. This is not in accordance with the safety and safety standards of sea transportation shipping, even in this area, there

This paper is presented in The $4^{\text {th }}$ International Conference on Maritime Education and Training October $8^{\text {th }}$, 2020, Makassar, Indonesia 
was an accident of the Jolloro ship type namely Arista which sank at the PaotereBarrang Lompo crossing on June 13, 2018.

\section{Research Method}

This research was conducted from August to December 2019. The research location was in the port of Paotere. This research approach is a qualitative descriptive using SWOT analysis. The SWOT analysis is used to compare the condition of ship construction, machinery and crew members with the factors that determine the criteria for strengthening the performance of public shipping safety services

\section{Results and Analysis}

\section{The suitability of the condition of the Seaworthy of Traditional Ships in Local \\ Makassar}

\subsection{Seaworthy Condition of Traditional Ships in Makassar}

The basic principle of shipping safety states that the ship that wants to sail must be in seaworthiness. In addition, the ship is fit to receive cargo and transport it and protect the safety of the cargo and crew. This is consistent with employee performance in implementing procedures, information on weather conditions, seaworthy conditions. In line with the results of data analysis that employees have the ability to apply the rules and procedures that have been set by the office in the excellent category 53.3\% (16 respondents) and the good category by $46.7 \%$ (14 respondents).

Republic of Indonesia Law Number 17 the Year 2008 concerning shipping Chapter IX Carrier Obligations and Responsibilities, Article 40 relating to transport responsibilities contain: 1) water transport companies are responsible for the safety and security of passengers and/or the goods they transport; 2) the water the transport company is responsible for the cargo of the ship according to the type and amount stated in the cargo document and/or the agreed transportation agreement or contract. This is consistent with the results of data analysis that determines and eliminates causes that cause accidents before the accident occurs in the good category $60.0 \%$ (18 respondents), the very good category is $36.7 \%$ (11 respondents), and the category is less good $3.3 \%$ (1 respondent).

The findings based on the Decree of DJPL No.HK.103/2/8/DJPL-17 concerning Traditional Ship Passenger Transport Guidance and findings in the field on the People's Sailing Vessels at the Paotere Port and Bangkoang Tumba Crossing can be seen in Table 1.

Table 1. Findings

\begin{tabular}{|l|l|l|}
\hline No. & Description & Finding \\
\hline 1 & Ship Condition & Observations made at the port condition of the ship is still good \\
\hline 2 & Load conditions & The cargo is still relatively normal \\
\hline 3 & Safety Equipment & $\begin{array}{l}\text { The average safety equipment is inadequate like Life Jacket does } \\
\text { not match the number of passengers and there is no fire } \\
\text { extinguisher }\end{array}$ \\
\hline 4 & Crew crewing & The average crew does not have a basic safety certificate (BST) \\
\hline 5 & Management Oversight & $\begin{array}{l}\text { Need strict supervision related to shipping safety in the city of } \\
\text { Makassar }\end{array}$ \\
\hline
\end{tabular}

Source: Field observation data, 2019

This paper is presented in The $4^{\text {th }}$ International Conference on Maritime Education and Training 100 


\subsection{Safety Management and Supervision of Sea Transportation in Makassar City}

The results of data analysis regarding the management of safety and supervision of sea transportation in Makassar City show that; Cooperation of 3 agencies involved in supervision in the very good category was $50.0 \%$ (15 respondents), and the good category was $46.7 \%$ (14 respondents), and the category was not very good $3.3 \%$ (1 respondent).

From the results of the study, it can be seen that the level of the satisfaction of organizational management performance is at the percentage of each category is shown in Table 2.

Table 2. Level of Satisfaction of Organizational Management Performance

\begin{tabular}{|l|l|l|l|l|}
\hline No. & Range & Frequency & Percentage & Category \\
\hline 1 & $161-168$ & 5 & $16.7 \%$ & Very good \\
\hline 2 & $153-160$ & 16 & $53.3 \%$ & good \\
\hline 3 & $145-152$ & 7 & $23.3 \%$ & Not good \\
\hline 4 & $137-144$ & 0 & $0 \%$ & bad \\
\hline 5 & $129-136$ & 2 & $6.7 \%$ & Very bad \\
\hline Total & $\mathbf{3 0}$ & $\mathbf{1 0 0}$ & \\
\hline
\end{tabular}

Source: Primary Data Processed, 2019

\subsection{SWOT Analysis}

The research was conducted and analyzed by SWOT method. The result as follow:

Internal Factor $=$ Strength - Weakness $=$ Leadership - Management

External Factor $=$ Threat - Opportunity $=$ Supervision - Job Result.

The conclusion from the analysis based on questionnaire taken is:

Internal Factor $=4,2-4,21=-0,01$ ( $\mathrm{X}$ axis, horizontal)

External Factor $=4,8-4,4=0,4$ (Y axis, vertical)
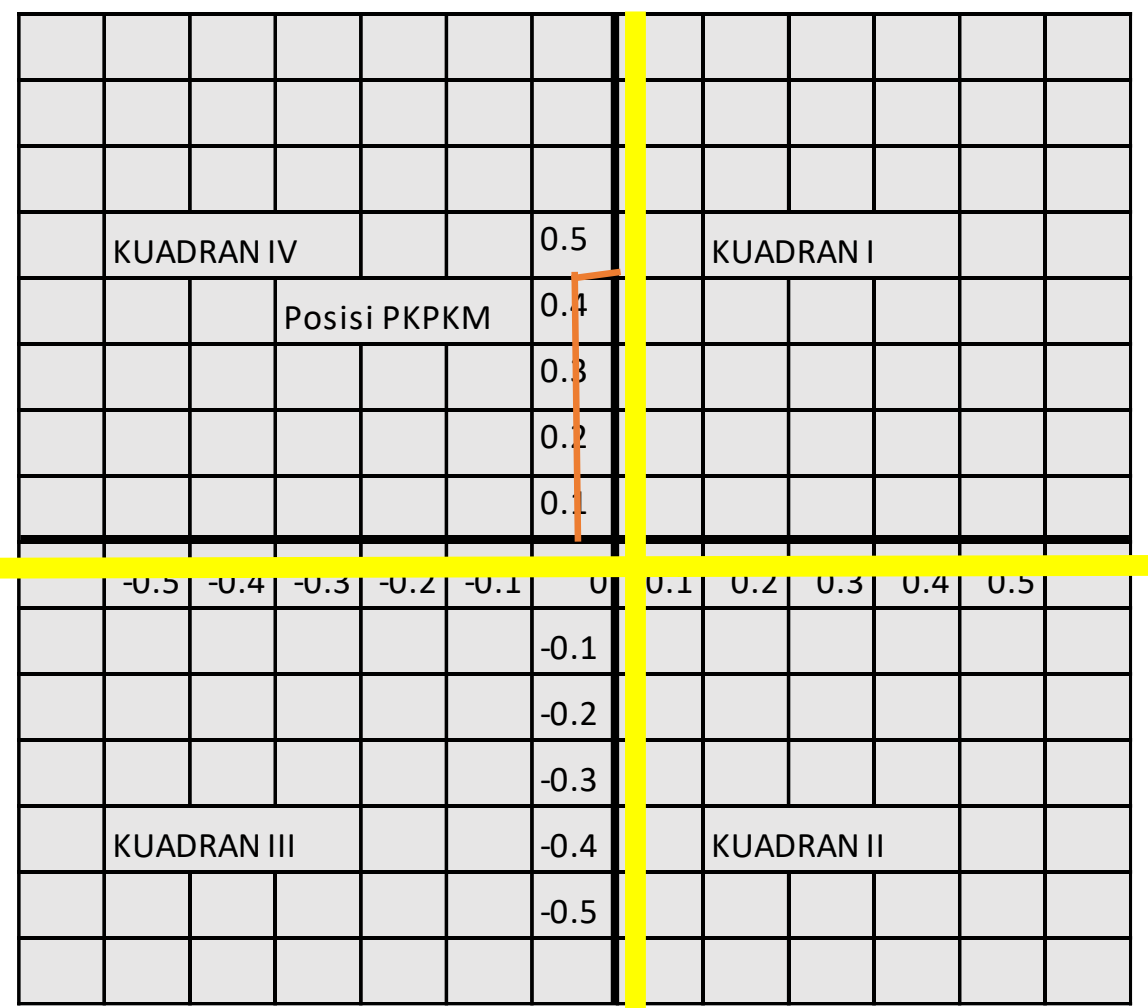

Figure 1.

This paper is presented in The $4^{\text {th }}$ International Conference on Maritime Education and Training 101 October $8^{\text {th }}$, 2020, Makassar, Indonesia 


\section{Improving the Safety of Local Sea Transportation in the Makassar City Water Region}

Increasing shipping safety in Indonesia follows international shipping safety. Although in reality, the government imposed Government Regulations on Shipping. Safety oversight is the Directorate of Sea Transportation and in practice are Syahbandar and his staff. Plans to reduce shipping accidents in the Makassar City waters area, namely:

1) Improve crew training through free Community Empowerment Training (CET) made by the Human Resources Development Agency (HRDA) of the Ministry of Transportation through the Technical Implementation Unit of the education and training underneath;

2) Make safety standards especially if the ship contains passengers;

3) Improve the competency of ship supervisors both from the port and transportation services based on the results of data analysis that conducts field supervision on ships once a week in the good category $60.0 \%$ (18 respondents), and the very good category by $40.0 \%$ (12 respondents);

4) Consolidation between the Syahbandar and the transportation service related to the supervision. This is consistent with the results of data analysis that the Department is one of the three best agencies within the scope of customer satisfaction in the excellent category of $50.0 \%$ ( 15 respondents), and a good category of $46.7 \%$ (14 respondents), and the category of less good 3.3\% (1 respondent);

5) Change safety management by adopting the first safety standard;

6) Syahdu Program (Syahbandar Educate) to the community, ship owners and Ship Crew. In line with the results of the data analysis that employees have the ability to apply the rules and procedures that have been set by the office in the excellent category $53.3 \%$ (16 respondents) and the good category by $46.7 \%$ (14 respondents)

\section{Conclusion}

The Condition of Seaworthiness of Traditional Ships regarding the implementation of procedures, information on weather conditions, seaworthiness conditions are in the very good category $53.3 \%$ and the good category by $46.7 \%$. The related department of marine transportation safety and supervision management in the city of Makassar has performed in accordance with applicable regulations and procedures to reduce the level of shipping accidents. Collaboration with 3 agencies involved in supervision so that the services provided in the category of very good $50.0 \%$, and good category amounted to $46.7 \%$, and the category of less good $3.3 \%$. Plans to reduce shipping accidents in Makassar City, namely related agencies, make Syahdu (Syahbandar Educate) Programs to the Public, Ship Owners and Ship Crew related to safety improvement by providing safety understanding and training. This is relevant to conducting field oversight on ships $1 \mathrm{x}$ a week in the Good category at $60.0 \%$ and the very good category at $40.0 \%$

The conclusion of swot analysis above shows that authority as the organization responsible for the safety of local shipping in the city of Makassar must immediately take a stance to overcome the threat by departing from internal factors namely strenghts and weaknesses, in line with those covered in quadrant IV that syahbandar or the Department of Transportation is weak in monitoring the enforcement of existing regulations, complex government bureaucracy processes and overlapping regulations

This paper is presented in The $4^{\text {th }}$ International Conference on Maritime Education and Training 102 October $8^{\text {th }}$, 2020, Makassar, Indonesia 


\section{References}

[1] Boulougouris, E., Cichowicz, J., Jasionowski, A., \& Konovessis, D. 2016. Improvement of ship stability and safety in damaged condition through operational measures: Challenges and opportunities. Ocean Engineering, 122, 311-316.

[2] European Maritime Heritage. 2009. Standard upon Safe Operation of Traditional Ships in European Waters and Standards required for Ship Safety Certification, Annex II

[3] EMSA. 2018. Annual Overview of Marine Casualties and Incidents 2017.

[4] Fawzi and Rita Irviani. 2018. Introduction to Management. Yogyakarta: ANDI Publisher.

[5] Haapasaari, P., Helle, I., Lehikoinen, A., Lappalainen, J., \& Kuikka, S. 2015. A proactive approach for maritime safety policy making for the Gulf of Finland: Seeking best practices. Marine Policy, 60, 107-118.

[6] http://hubla.dephub.go.id/berita/Pages/Kemenhub-Terbitkan-Aturan-PetunjukKapal-Tradisional-Pengangkut-Penumpang.aspx

[7] Minister of Transportation Instruction Number IM 1 of 2013 concerning the Action Plan for Improving Transportation Safety http://www.makassarkota.go.id. Accessed March 10, 2019.

[8] Malisan Johny, Jinca M.Y., Parung Herman, and Saleng Abrar, 2013. Traditional Shipping Transport Safety Case Study: Phinisi Fleet (A study on stability, strength and human resources), International Refereed Journal of Engineering and Science (IRJES) ISSN (Online) 2319-183X, (Print) 2319-1821 Volume 2, Issue 2(February 2013), PP.01-10.

[9] Jinca M.Y. 2002. Pinisi sail boat marine transportation: Technology and Management of the People's Shipping Industry. Hasanuddin University Publishing Institute. Makassar

[10] Jinca M.Y. 2007. Sea Transportation and Crossing Safety, Indonesian Transportation Society National Coordination Meeting. Semarang

[11] Decree of the Director General of Sea Transportation Number: PY.66/1/2-02 concerning Safety Requirements for Dirty Tonnage Motorized Motorized Boat (KLM) up to GT 500.

[12] NTSC. 2018. Sailing Accident Investigation Report: Arista Sinking in 1.7 Nautical Mile of Port of Paotere, Makassar, South Sulawesi

[13] NTSC. 2016. Shipping Accident Investigation Data for 2010 to 2016. Media Release NTSC

[14] Kopacz Z., Morgao,, W. and Urbaūski, J. 2001. The Maritime Safety System; Its components and elements. The Journal of Navigation, pp. 199-211.

[15] Lubis, Y., Hermanto, B., \& Edison, E. (2018). Human Resources Management and Research. Bandung: Alfabeta

[16] Notification of the Directorate General of Sea Transportation Number: 190/XII/DU-16 dated 7 December 2016 concerning the Obligation to Implement Shipping Safety and Security Oversight.

[17] Munawar Ahmad. 2007. Sustainable Transportation Development. Inauguration Speech of UGM Faculty of Engineering Professor. Yogyakarta

[18] Nurwahida. 2003. Perceptions of Decision Making against the Implementation of the Safety Management standards of the Traditional Shipping Vessels. Thesis of Post-graduate Hasanuddin University. Makassar.

This paper is presented in The $4^{\text {th }}$ International Conference on Maritime Education and Training 103 
[19] Regulation of the Head of Transportation Education and Training Agency Number: SK.225/DL.002/II/Diklat-2010 concerning Basic Safety Training (BST) Specifically for Crew Crews and Workers on Motorcycle Sailboats and Fishing Vessels Domestic.

[20] Government Regulation Number 20 of 2010 concerning Water Transportation.

[21] Roe, M. 2013. Maritime Governance and Policy-Making. (Vol.9781447141532, pp. 1-442). Springer-Verlag London Ltd.

[22] Rothblum AM, Wheal D, Withington S, Shappel SA, Wiegmann D.A. 2002. Improving incident investigation through inclusion of human factors.

[23] Law of the Republic of Indonesia Number 17 Year 2008 concerning Shipping

[24] Republic of Indonesia Law No. 17 of 1985 concerning Ratification of the United Nations Convention on the Law of the Sea (UNCLOS) 1982. Jakarta: UURI

[25] United Nations ESCAP. 2016. The Improvement of Maritime Transport Safety in the Escap Region. Korea Maritime Institute. 